\title{
Sonogashira cross-couplings of dehydroamino acid derivatives and phenylacetylenes
}

\author{
Ana S. Abreu, ${ }^{a}$ Paula M. T. Ferreira, ${ }^{\text {a }}$ Maria-João R. P. Queiroz, ${ }^{\text {* }}$ Emanuela \\ Gatto, ${ }^{b}$ Mariano Venanzi ${ }^{\text {b }}$ \\ ${ }^{a}$ Departamento de Química-Universidade do Minho, Gualtar \\ 4710-057 Braga (Portugal) \\ ${ }^{\mathrm{b}}$ Department of Chemical Sciences and Technologies, University of Tor Vergata \\ 00133 Rome (Italy)
}

*Corresponding author:

Fax: +351253678983

E-mail: mjrpq@quimica.uminho.pt

Received

Keywords: Amino acids / phenylacetylenes / Sonogashira coupling / palladium / benzo[b]thiophenes/ fluorescence

Several phenylacetylenes were coupled under Sonogashira cross coupling conditions with the methyl esters of $N$-(tert-butoxycarbonyl)-(E)- $\beta$-bromo or $\beta, \beta$-dibromodehydroalanine to give respectively $\beta$-substituted or $\beta, \beta$-bis-substituted dehydroalanines. The $\beta$-substituted dehydroalanines were obtained in good to high yields (60-90\%) under the usual Sonogashira conditions (1 equiv. of the phenylacetylene, $1 \mathrm{~mol} \% \mathrm{Pd}\left(\mathrm{PPh}_{3}\right)_{4}, 2 \mathrm{~mol} \% \mathrm{CuI} 18$ equiv. $\mathrm{NEt}_{3}$ in acetonitrile, $24 \mathrm{~h}$ at $\mathrm{rt}$ ) with maintenance of the stereochemistry. The $\beta, \beta$-bis-substituted dehydroalanines were in turn obtained in moderate to good yields (44-63\%) requiring modified Sonogashira conditions (4 equiv. of the phenylacetylene,10 mol\% $\mathrm{PdCl}_{2}\left(\mathrm{PPh}_{3}\right)_{2}, 20 \mathrm{~mol} \% \mathrm{CuI}$, 1.4 equiv. $\mathrm{Cs}_{2} \mathrm{CO}_{3}, 2 \mathrm{~h}$ at reflux of acetonitrile). In the latter reactions some phenylacetylene dimer and the $(E)$-isomer of the mono substituted coupled products were also isolated in some extent.

The Sonogashira products which were obtained from the 4-bromophenylacetylene were reacted with functionalized benzo[b]thiophenes under C-C or C-N palladium-catalyzed cross-coupling conditions. 
Preliminary fluorescence studies were performed for mono and disubstituted 4aminophenylacetylenic dehydroamino acids and for the benzo[b]thiophene derivatives. The results showed that some of the dehydroalanines prepared can be used as fluorescent probes.

\section{Introduction}

In recent years dehydroamino acids have shown to be versatile substrates for the synthesis of novel amino acids. ${ }^{[1,2]}$

We have been interested in the synthesis of benzo[b]thienylamino acids that can have biological activity or can be used as fluorescent probes when inserted into peptides. ${ }^{[3]}$ Using several differently functionalized benzo $[b]$ thiophenes we were able to synthesize new amino acids and dehydroamino acids either by Suzuki coupling or by sequential Michael addition and C-C (Suzuki) or C-N palladium catalyzed cross couplings. ${ }^{[4 a-c]}$

Some ethynylamino acid derivatives have been isolated from microorganisms or prepared by various methods and have shown biological activities. ${ }^{[5]}$ Sonogashira cross-coupling have been used in the synthesis of alkynylamino acid derivatives having the triple bond either in the amino acid side chain ${ }^{[6,7]}$ or in the amino function. ${ }^{[8]}$

Here we describe the use of Sonogashira cross-coupling for the synthesis of dehydroamino acids reacting $\beta$-bromo or $\beta, \beta$-dibromodehydroalanine derivatives with several phenylacetylenes. The extra functions of some of the coupled products were reacted with functionalized benzo $[b]$ thiophenes by palladium catalyzed $(\mathrm{C}-\mathrm{C}$ or $\mathrm{C}-\mathrm{N})$ cross couplings. The acetylenic dehydroamino acids obtained can have biological activity and some of them can be used as probes when inserted into peptides due to their fluorescence properties.

\section{Results and Discussion}

The methyl esters of $N$-(tert-butoxycarbonyl)-(E)- $\beta$-bromo ${ }^{[4 a]}$ and $\quad \beta, \beta$ dibromodehydroalanine ${ }^{[4 \mathrm{c}]}$ were coupled with several phenylacetylenes under different Sonogashira conditions to give the corresponding coupled products (Scheme 1 and Scheme 2).

The coupled products $(\boldsymbol{E})-1 \mathrm{a}-\mathrm{c}$ were obtained in good to high yields $(60-90 \%)$ from the methyl ester of $N$-(tert-butoxycarbonyl)-(E)- $\beta$-bromodehydroalanine, under the usual Sonogashira coupling conditions ${ }^{[6,9]}$ (Scheme 1). In this reaction $\mathrm{NEt}_{3}$ is usually used as base and solvent ( $\sim 18$ equiv.) but in our case it was necessary to add a small amount of acetonitrile due to the low solubility of the starting materials in $\mathrm{NEt}_{3}$.

The stereochemistry of the products was determined by NOE difference experiments, observing an enhancement of the $\beta \mathrm{CH}$ signal when the $\alpha \mathrm{NH}$ was irradiated. 


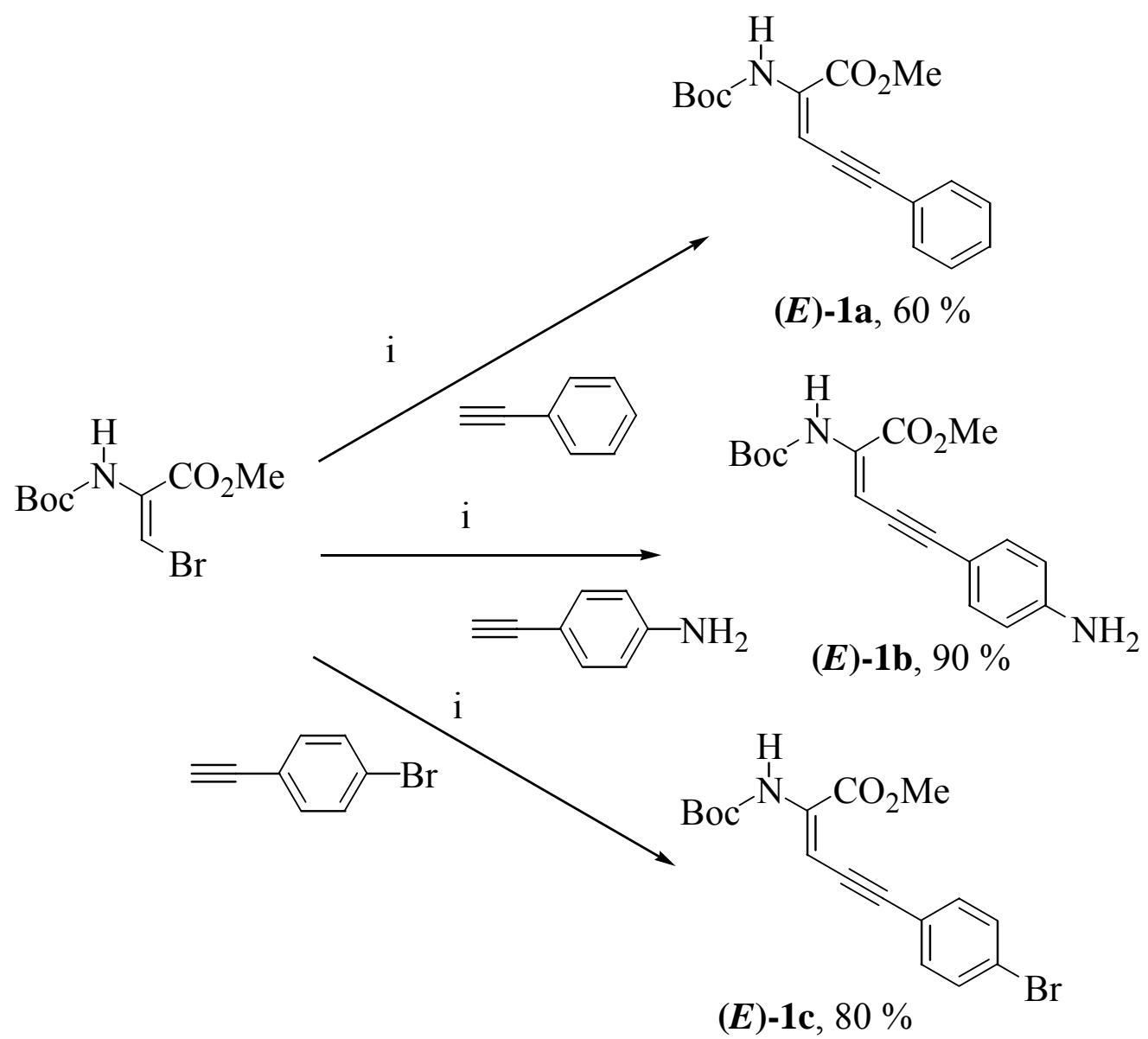

i) 1equiv. of the phenylacetylene, $1 \mathrm{~mol} \% \mathrm{Pd}\left(\mathrm{PPh}_{3}\right)_{4}, 2 \mathrm{~mol} \% \mathrm{CuI}, 18$ equiv. $\mathrm{NEt}_{3}$ in acetonitrile, $24 \mathrm{~h}$ at rt.

\section{Scheme 1}

The reaction yields significantly increased with the para-substitution in the phenylacetylene either with a bromine atom or an amino group.

The same reaction conditions applied to the coupling of the methyl ester of $N$-(tertbutoxycarbonyl)- $\beta, \beta$-dibromodehydroalanine with 4 -aminophenylacetylene ( 2 equiv.) gave only the monosubstituted derivative $(\boldsymbol{E})-\mathbf{1 b}$ in $35 \%$ yield and the corresponding phenylacetylene dimer in a significant amount. The isolation of the $E$-isomer could be due to the fact that the first oxidative addition occurs at the less hindered side of the carbon halogen bonds as observed by other authors with 1,1-dibromo-1-alkenes. ${ }^{[10]}$

After several experiments the best conditions to obtain disubstituted coupled products from the $\beta, \beta$-dibromodehydroalanine derivative are shown in Scheme 2. Compounds 2a-c were isolated in moderate to good yields together with a small amount of the corresponding monosubstituted (E)-isomer and the phenylacetylene dimers. The change of $\mathrm{NEt}_{3}$ to $\mathrm{Cs}_{2} \mathrm{CO}_{3}$ shown to be crucial 
in order to obtain the disubstituted coupled products. In fact even lowering the amount of $\mathrm{NEt}_{3}$ to 9 equiv., in the coupling of phenylacetylene with the dibromo compound only the monosubstituted compound (E)-1a and the phenylacetylene dimer were isolated. The use of 1.4 equiv. of $\mathrm{Cs}_{2} \mathrm{CO}_{3}$ gave the best yields for the disubstituted compounds. In the coupling of 4aminophenylacetylene using 2.8 equiv. of $\mathrm{Cs}_{2} \mathrm{CO}_{3}$, the disubstituted product $\mathbf{2 b}$ was only obtained in $10 \%$ yield together with $20 \%$ of the monosubstituted $(\boldsymbol{E})-\mathbf{1 b}$ with increase of the amount of the corresponding dimer. Higher yields of the disubstituted products were obtained when the reactions were carried out at reflux of acetonitrile instead of room temperature and when $\mathrm{PdCl}_{2}\left(\mathrm{PPh}_{3}\right)_{2}$ was used. Compound 2a was obtained in only $25 \%$ yield together with the (E)-1a in 27\% yield and the corresponding acetylene dimer, using the best conditions but stirring for $18 \mathrm{~h}$ at room temperature.

The different reaction yields for compounds 2a-c are explained by the amounts of the corresponding phenylacetylene dimers obtained (see experimental). 


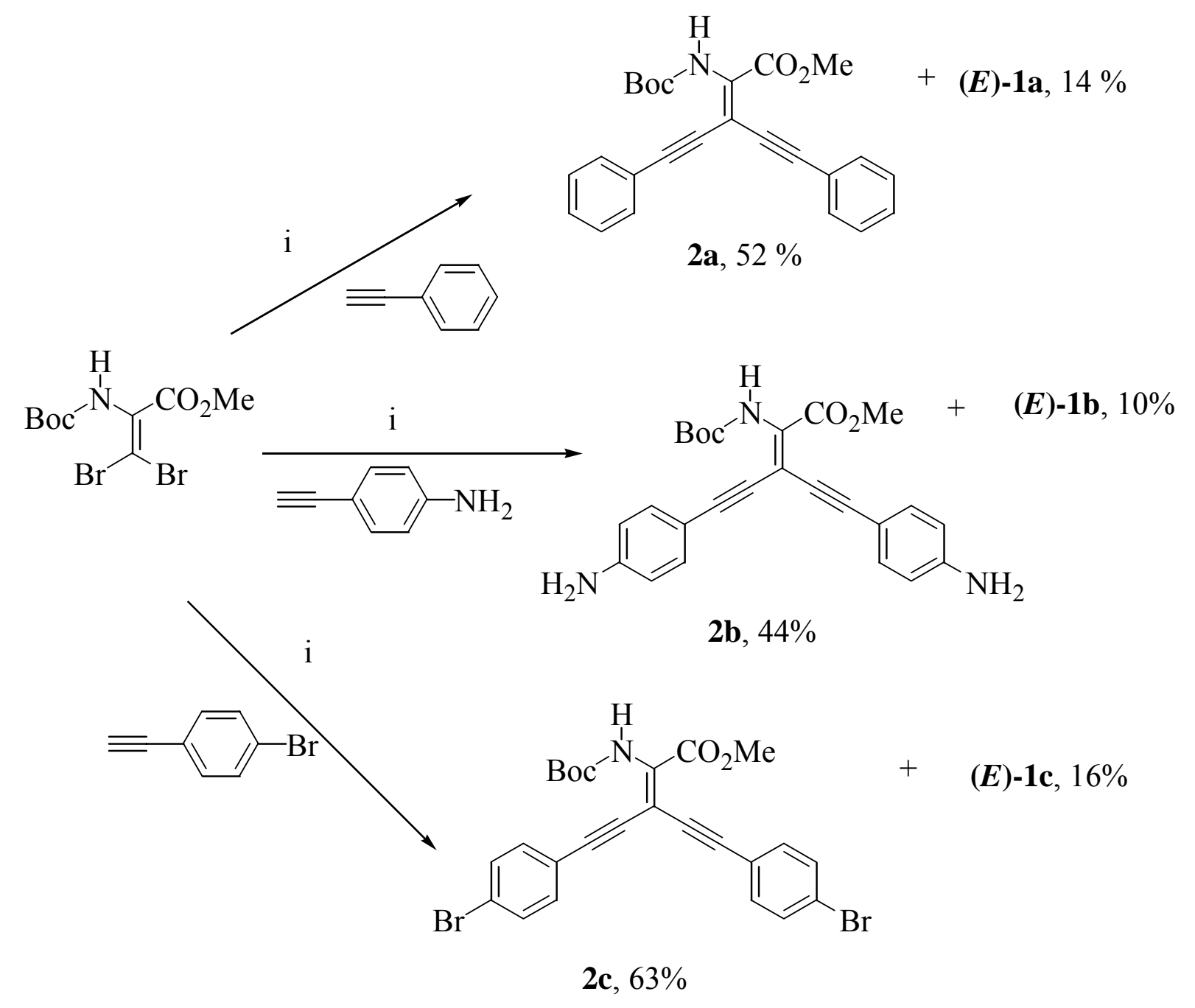

i) 4 equiv. of the phenylacetylene, $10 \mathrm{~mol} \% \mathrm{PdCl}_{2}\left(\mathrm{PPh}_{3}\right)_{2}, 20 \mathrm{~mol} \% \mathrm{CuI}$, 1.4 equiv. $\mathrm{Cs}_{2} \mathrm{CO}_{3}, 2 \mathrm{~h}$ at reflux of acetonitrile

Scheme 2

Compounds $(\boldsymbol{E})$-1c and 2c were reacted using palladium-catalyzed $\mathrm{C}-\mathrm{C}$ and $\mathrm{C}-\mathrm{N}$ cross-couplings with functionalized benzo $[b]$ thiophenes. 3-Boronic benzo $[b]$ thienyl acid was reacted under Suzuki cross coupling conditions ${ }^{[4 \mathrm{~b}]}$ with compound $(\boldsymbol{E})-\mathbf{1 c}$ to give compound $\mathbf{3}$ in $50 \%$ yield and 3,3'-bis-benzo[b]thiophene (18\%) (Scheme 3). Compound 2c was reacted with 7-amino-2,3dimethylbenzo $[b]$ thiophene ${ }^{[4 b]}$ under $\mathrm{C}-\mathrm{N}$ palladium-catalyzed cross-coupling conditions ${ }^{[4 \mathrm{~b}]}$ to give compound 4 in $40 \%$ yield together with the starting aminobenzo[b]thiophene $(40 \%)$ due to some decomposition of the starting dehydroamino acid (Scheme 4). 
(E)-1c

Scheme 3

$$
\begin{aligned}
& \text { Pd(OAc) } 20 \mathrm{~mol} \% \\
& \text { BINAP } 30 \mathrm{~mol}^{\circ} \\
& 2.8 \text { equiv. } \mathrm{Cs}_{2} \mathrm{CO}_{3} \\
& \text { toluene, } 100{ }^{\circ} \mathrm{C}, \mathrm{Ar} \\
& \text { lh30min }
\end{aligned}
$$

(E)-3, 50\%<smiles>COC(=O)/C(=C\C#Cc1ccc(-c2csc3ccccc23)cc1)NC(=O)c1ccccc1</smiles> 
Condon energy gap. The linkage of a second 4-aminophenylacetylene strongly perturbs the spectral profile of compound $\mathbf{2 b}$, shifting its lowest energy absorption band to shorter wavelenghts and splitting it in two components. These findings suggest the occurrence of a strong electronic coupling between the two phenylacetylenic groups in compound $\mathbf{2} \mathbf{b}$. The exciton-like character of this interaction is proved by the splitting of the lowest energy absorption band, while the shift to shorter wavelengths indicates the predominant stabilization of the chromophore ground state with respect to the electronic excited state.

This interaction is also responsible for the different fluorescence properties of the compounds (E)-1b and 2b (Fig.2). The emission of (E)-1b is hardly detectable, implying that its lowest energy excited state decays through very efficient non radiative relaxation processes. This is probably due to the electronic coupling of the phenylacetylene moiety with non radiative electronic states of the dehydroamino acid (internal conversion).

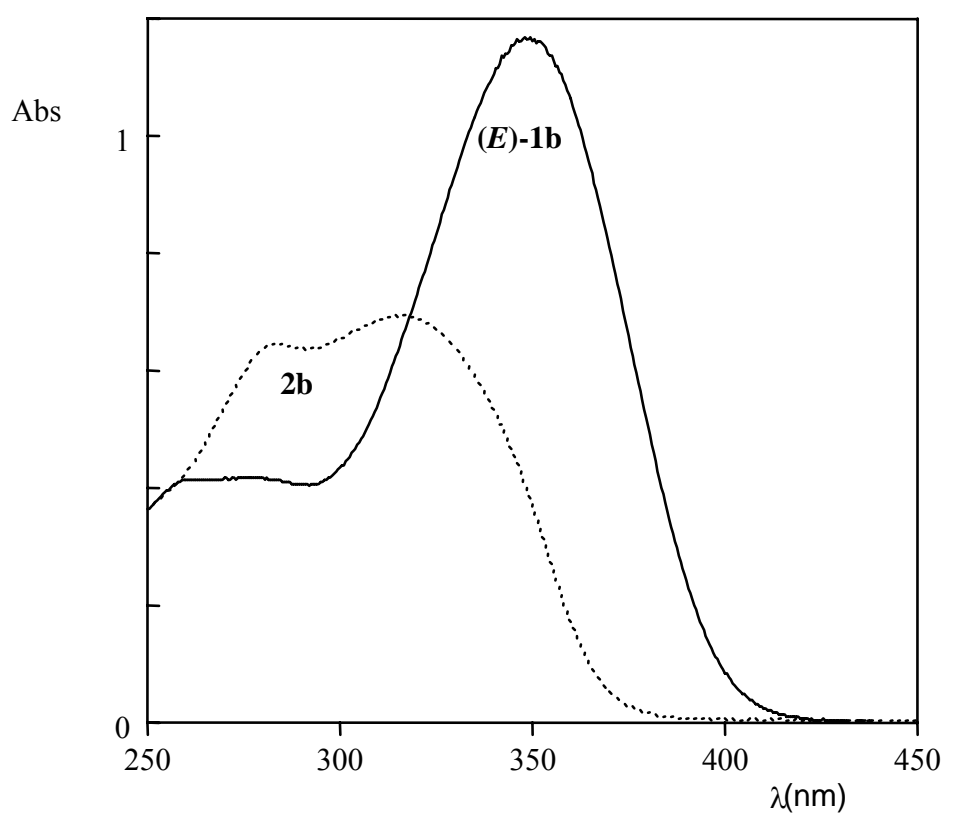

Fig.1 - Absorption spectra of compounds (E)-1b and $\mathbf{2 b}$ in dichloromethane. 


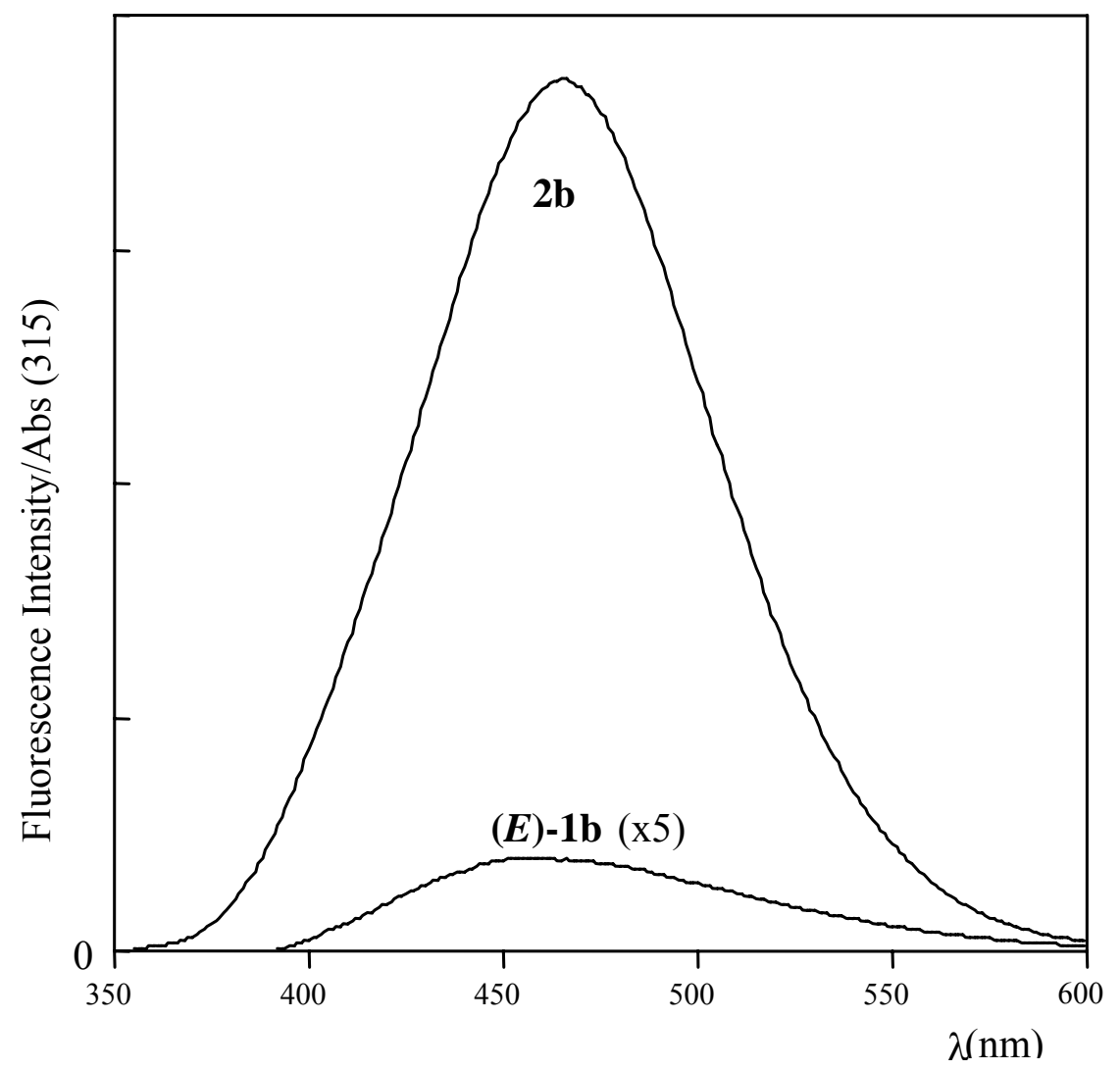

Fig. 2 - Fluorescence spectra of compounds $(\boldsymbol{E}) \mathbf{- 1} \mathbf{b}$ and $\mathbf{2 b}$, in dichloromethane.

The high fluorescence quantum yield of compound $\mathbf{2 b}$ suggests that the linkage of a second 4aminophenylacetylene weakens the electronic coupling with the dehydroamino acid moiety, decreasing the efficiency of non radiative processes. The polar character of the new emissive state is proved by the strong solvent dependence of compound $\mathbf{2 b}$ emission (Fig. 3). Lower quantum yields and longer lifetimes in polar solvents are typical of radiative charge transfer states, ${ }^{[1]}$ as consistently shown by the fluorescence properties of the compound $\mathbf{2} \mathbf{b}$ in acetonitrile (Table 1). The time-resolved fluorescence decay of the latter compound is described by a two exponential function in both solvents studied, implying that at least two different electronic states contribute to its emission. 


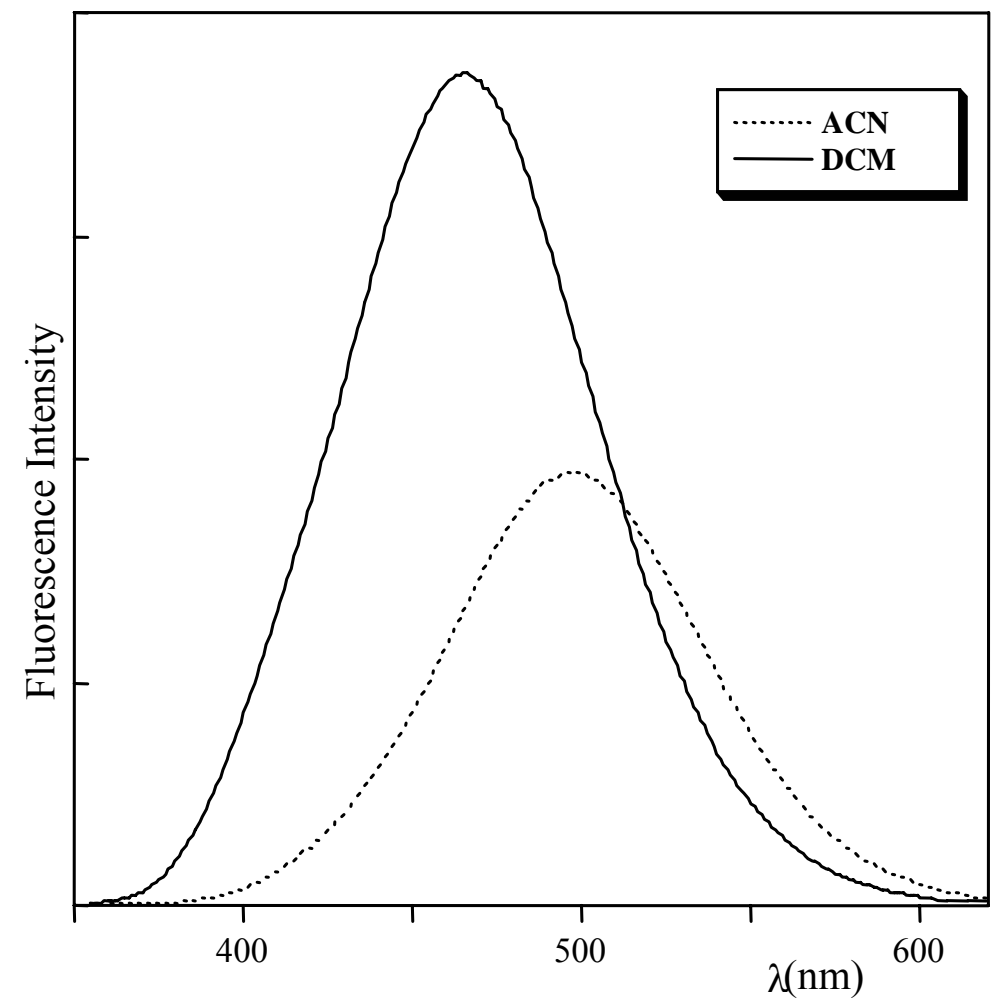

Fig.3 - Fluorescence spectra of compound $\mathbf{2 b}$ in dichloromethane (DCM) and acetonitrile (ACN)

Table 1 - The fluorescence lifetimes $\left(\tau_{\mathrm{i}}\right)$, pre-exponential factors $\left(\alpha_{\mathrm{i}}\right)$ and quantum yields $(\phi)$ for compound $\mathbf{2 b}$.

\begin{tabular}{|l|c|c|c|c|c|c|c|}
\hline Solvent & $\lambda_{\text {em }}(\max , \mathrm{nm})$ & $\phi^{\mathbf{a}}$ & $\tau_{\mathbf{1}}(\mathrm{ns})$ & $\alpha_{\mathbf{1}}$ & $\tau_{2}(\mathrm{~ns})$ & $\alpha_{2}$ & $<\tau>(\mathrm{ns})^{\mathbf{b}}$ \\
\hline Dichloromethane & 467 & $0.03 \pm 0.01$ & 0.27 & 0.98 & 1.94 & 0.02 & 0.31 \\
\hline Acetonitrile & 498 & $0.01 \pm 0.01$ & 0.74 & 0.98 & 2.66 & 0.02 & 0.78 \\
\hline
\end{tabular}

a) with respect to anthracene in ethanol $(\phi=0.27 \pm 0.01)$.

b) $\left\langle\tau>=\alpha_{1} \tau_{1}+\alpha_{2} \tau_{2}\right.$

The absorption spectra of the compound $(\boldsymbol{E})-3$ is dominated at low energies by the $\pi, \pi^{*}$ transitions of the phenylacetylene moiety, as shown in Fig. 4. The absorption profile of compound 4 shows, with respect to the spectrum of the compound $(\boldsymbol{E})-\mathbf{3}$, a broader band, suggesting the occurrence of a second spectral component associated at shorter wavelengths to the aminobenzothiophene group. 


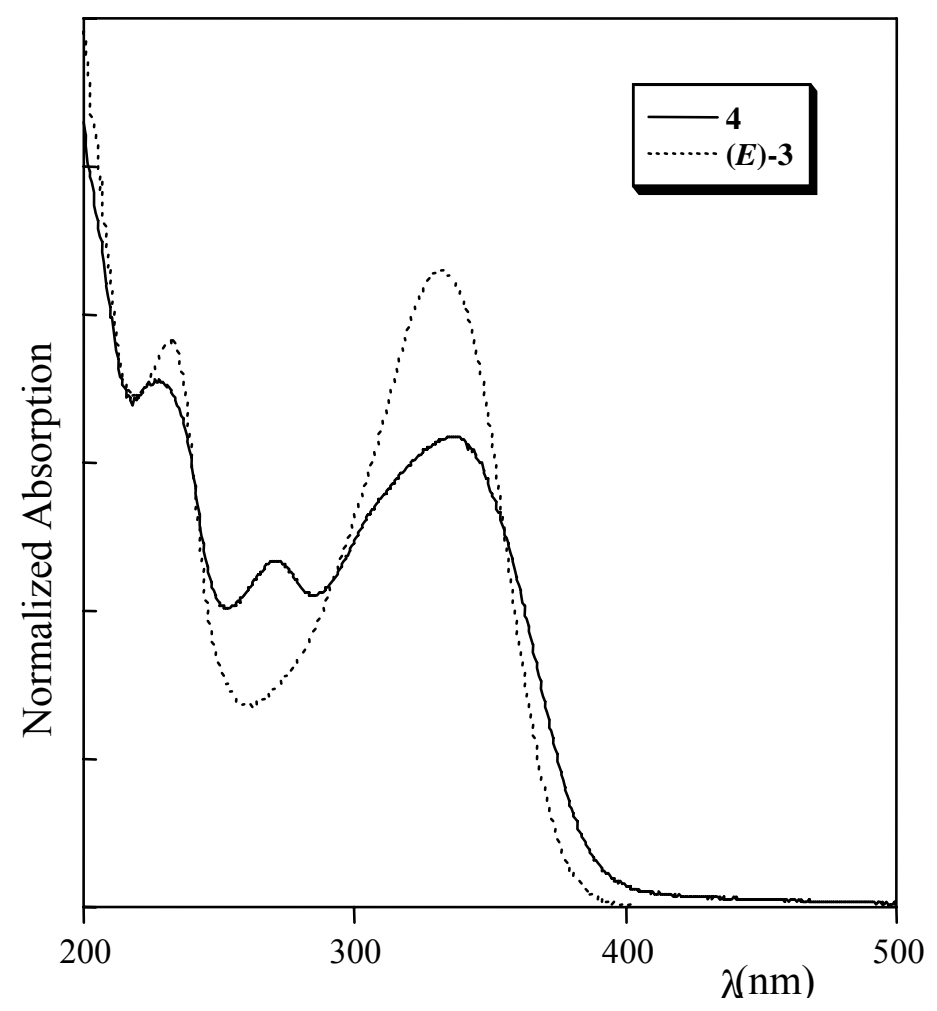

Fig. 4 - Absorption spectra of compounds (E)-3 and $\mathbf{4}$ in acetonitrile (ACN).

The fluorescence time decay of compound $(\boldsymbol{E})-3$ is described by a single exponential function (Table 2) and its emission quantum yield is notably higher than that one of compound $\mathbf{4}$, as shown in Figure 5. These findings suggest that the excited state electronic distribution of $(\boldsymbol{E})-3$ is localized on the phenylacetylene moiety.

The emission quantum yield of compound $\mathbf{4}$ is very low and its time decay is described by two time components (Table 2). Due to extensive overlap between the aminobenzothiophene fluorescence and the phenylacetylene absorption a complete intramolecular energy transfer process occurs, leading to emission only from the phenylacetylene moiety. The presence in compound 4 of an amino group (a strong electron donor) bridging the benzothiophene and the phenylacetylene group distributions favors the formation of an intramolecular charge transfer (ICT) state. ICT states are characterized by very low quantum yield and relatively slow decay times, ${ }^{[11]}$ as revealed by the second time component (Table 2) found in the time resolved fluorescence measurement. This interaction has been found in other aminobenzothiophene-based compounds and is currently under investigation in our laboratory. 


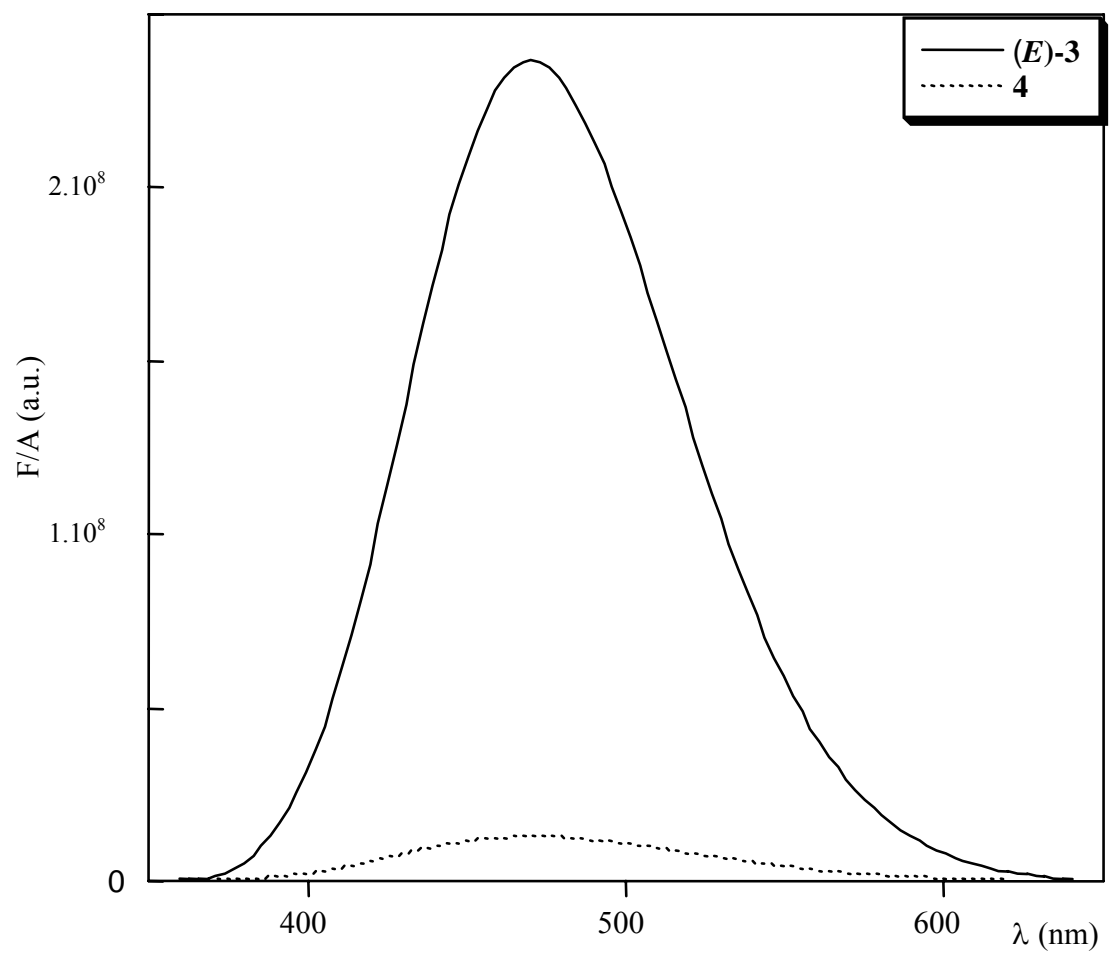

Fig.5 - Fluorescence spectra of compounds (E)-3 and 4 in ACN $\left(\lambda_{\text {exc }} 330 \mathrm{~nm}\right)$.

Table 2- Fluorescence data of compounds $(\boldsymbol{E})-\mathbf{3}$ and $\mathbf{4}$ in acetonitrile.

\begin{tabular}{|c|c|c|c|c|c|c|}
\hline Compound & $\lambda_{\text {em }}(\max , \mathrm{nm})$ & $\phi^{\mathbf{a}}$ & $\tau_{\mathbf{1}}(\mathrm{ns})$ & $\alpha_{1}$ & $\tau_{2}(\mathrm{~ns})$ & $\alpha_{2}$ \\
\hline$(\boldsymbol{E})-3$ & 471 & 0.14 & 1.2 & 1.0 & -- & \\
\hline $\mathbf{4}$ & 471 & 0.006 & 0.8 & 0.96 & 2.5 & 0.04 \\
\hline
\end{tabular}

a) with respect to anthracene in ethanol $(\phi=0.27 \pm 0.01)$.

These preliminary results suggest that compounds $\mathbf{2 b}$ and $(\boldsymbol{E})-\mathbf{3}$ can be used as fluorescent probes when inserted into peptides. A proper selection of the chromophores and the fine tuning of the interactions that involve the aromatic moieties could be usefully exploited to modulate the fluorescence properties of the newly designed compounds.

\section{Conclusions:}

Several new acetylenic $\alpha, \beta$-dehydroamino acids were prepared using Sonogashira crosscoupling. Different conditions were established to obtain either eneyne or "ene-diyne" amino acids. The dehydroamino acids having a bromine atom in their side chains, $(\boldsymbol{E})-\mathbf{1 c}$ and $2 \mathbf{c}$, were coupled with benzo[b]thiophenes by $\mathrm{C}-\mathrm{C}$ (Suzuki) or $\mathrm{C}-\mathrm{N}$ palladium-catalyzed cross-couplings to give the benzo[b]thienyl amino acids $(\boldsymbol{E})-\mathbf{3}$ and $\mathbf{4}$. 
The photophysical properties of four of the compounds obtained, were studied. The results suggest that two of them can be used as fluorescent markers.

\section{Experimental Section}

General Remarks: Melting points were determined on a Gallenkamp apparatus and are uncorrected. The ${ }^{1} \mathrm{H}$ NMR spectra were measured on a Varian Unity Plus at $300 \mathrm{MHz}$. Spin-spin decoupling techniques were used to assign the signals. NOE experiments were performed to determine the stereochemistry of the products. The ${ }^{13} \mathrm{C}$ NMR spectra were measured in the same instrument at $75.4 \mathrm{MHz}$ (using DEPT $\theta 45^{\circ}$ ). Elemental analyses were determined on a LECO CHNS 932 elemental analyser. Mass spectra (EI and FAB) and HRMS were made by the mass spectrometry service of University of Vigo-Spain.

Steady-state fluorescence spectra were recorded on a Fluoromax spectrofluorimeter (Jobin-Yvon, France), operating in SPC (Single Photon Counting) mode. Quantum yields were obtained by using anthracene in ethanol as reference: $\phi_{0}=0.27 \pm 0.01$. Samples quantum yields are given by:

$$
\Phi_{\mathrm{s}}=\frac{\mathrm{A}_{\mathrm{r}} \mathrm{F}_{\mathrm{s}} \mathrm{n}_{\mathrm{s}}^{2}}{\mathrm{~A}_{\mathrm{s}} \mathrm{F}_{\mathrm{r}} \mathrm{n}_{\mathrm{r}}^{2}} \Phi_{\mathrm{r}}
$$

where $\mathrm{A}$ is the absorbance at the excitation wavelength, $\mathrm{F}$ the integrated emission area and $\mathrm{n}$ the refraction index of the solvent used. Subscripts refer to the reference (r) or sample (s) compound. Nanosecond time decays were measured by a CD-900 (Edinburgh Instruments, Edinburgh, U.K.) lifetime apparatus with SPC detection. Excitation in the UV region was achieved by a flashlamp filled with ultrapure hydrogen $(300 \mathrm{mmHg})$, working at a repetition rate of $30 \mathrm{kHz}$. Under these conditions the full width at half maximum (FWHM) of the excitation profile was 1.2 ns. Experimental decay curves were fitted by a non linear least-squares analysis to exponential functions or time distributions through an iterative deconvolution method, by using a standard software licensed by Edinburgh Instruments. All fluorescence experiments were carried out in quartz cells, using solutions previously bubbled for 20 min with ultrapure nitrogen. All solutions for fluorescence measurements were freshly prepared at micromolar concentrations [absorbances less than $0.1(1=1 \mathrm{~cm})$ to avoid inner filter effects]. Excitation wavelengths used are as follows. (E)-1b: $\lambda_{\text {exc }}=360 \mathrm{~nm} ; 2 \mathbf{b}: \lambda_{\text {exc }}=321 \mathrm{~nm} ;(\boldsymbol{E})-3: \lambda_{\text {exc }}=334 \mathrm{~nm} ; 4: \lambda_{\text {exc }}=334 \mathrm{~nm}$.

Column chromatography was performed on Macherey-Nagel silica gel 230-400 mesh. Petroleum ether refers to the boiling range $40-60{ }^{\circ} \mathrm{C}$. Ether refers to diethyl ether. When solvent gradient was used the increase of polarity was done gradually from neat petroleum ether to mixtures of ether/petroleum ether increasing $10 \%$ of ether until the isolation of the product.

General procedure for Sonogashira Cross Coupling using the methyl ester of $N$-(tert-butoxycarbonyl)-(E)- $\beta$ bromodehydroalanine and phenylacetylenes: To a solution of compound Boc- $(E)-\Delta \mathrm{Ala}(\beta-\mathrm{Br})-\mathrm{OMe}(1 \mathrm{mmol} ; 280$ $\mathrm{mg}$ ) in triethylamine (18 equiv.), $\mathrm{CuI}(2 \mathrm{~mol} \%, 4.00 \mathrm{mg}), \mathrm{Pd}\left(\mathrm{PPh}_{3}\right)_{4}(1 \mathrm{~mol} \% ; 11.0 \mathrm{mg})$ were added, followed by the alkyne ( 1 equiv.), dissolved in acetonitrile $(0.5 \mathrm{~mL})$, with rapid stirring at room temperature, under argon. The reaction was left for $24 \mathrm{~h}$. The acetonitrile was removed under reduced pressure and the residue was dissolved in 30 $\mathrm{mL}$ of ethyl acetate. The organic layer was then washed with water and brine $\left(2 \times 15 \mathrm{~mL}\right.$ each), dried over $\mathrm{MgSO}_{4}$ and evaporated at reduced pressure giving an oil, which was submitted to column chromatography. 


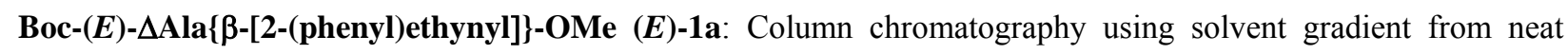
petroleum ether to $50 \%$ ether/petroleum ether, gave product $(E)-1 \mathbf{a}(178 \mathrm{mg}, 60 \%)$ as an oil. Recrystallization from ether/petroleum ether gave yellow crystals, mp 108.8-109.5 ${ }^{\circ} \mathrm{C} .{ }^{1} \mathrm{H}$ NMR $\left(\mathrm{CDCl}_{3}\right): \delta=1.49\left(\mathrm{~s}, 9 \mathrm{H}, \mathrm{CH}_{3} \mathrm{Boc}\right), 3.84$ (s, 3H, $\left.\mathrm{OCH}_{3}\right), 6.28(\mathrm{~s}, 1 \mathrm{H}, \beta \mathrm{CH}), 6.60$ (broad s, $\left.1 \mathrm{H}, \mathrm{NH}\right), 7.33-7.35$ (m, 3H, ArH), 7.46-7.49 (m, 2H, ArH) ppm.

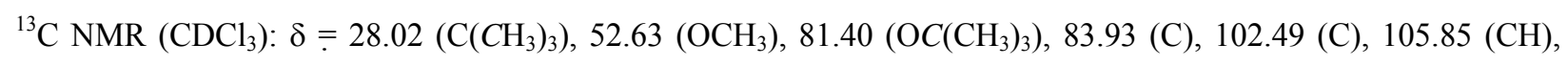
$122.41(\mathrm{C}), 128.33(\mathrm{CH}), 129.01(\mathrm{CH}), 131.65(\mathrm{CH}), 134.86(\mathrm{C}), 151.71(\mathrm{C}=\mathrm{O}), 164.36(\mathrm{C}=\mathrm{O}) \mathrm{ppm} . \mathrm{C}_{17} \mathrm{H}_{19} \mathrm{NO}_{4}$ (301.34): calcd. C 67.76, H 6.35, N 4.65; found C 67.50, H 6.34, N 4.75.

Boc-(E)- $\Delta$ Ala $\{\beta$-[2-(4-aminophenyl)ethynyl]\}-OMe (E)-1b: Column chromatography using as solvent ether, gave product $(\boldsymbol{E})$-1b (284 mg, 90\%) as a yellow solid. Recrystallization from ether gave yellow crystals, mp 107.8-108.8 ${ }^{\circ} \mathrm{C} .{ }^{1} \mathrm{H}$ NMR $\left(\mathrm{CDCl}_{3}\right): \delta=1.50$ (s, 9H, $\left.\mathrm{CH}_{3} \mathrm{Boc}\right), 3.83\left(\mathrm{~s}, 3 \mathrm{H}, \mathrm{OCH}_{3}\right), 3.91\left(\right.$ broad s, $\left.2 \mathrm{H}, \mathrm{NH}_{2}\right), 6.30(\mathrm{~s}, 1 \mathrm{H}, \beta \mathrm{CH})$, 6.45 (broad s, 1H, NH), $6.62\left(\mathrm{~d}, J=8.4 \mathrm{~Hz}, 2 \mathrm{H}, \mathrm{ArH}\right.$ ortho to the $\mathrm{NH}_{2}$ ), $7.29(\mathrm{~d}, J=8.4 \mathrm{~Hz}, 2 \mathrm{H}$, ArH meta to the $\left.\mathrm{NH}_{2}\right)$ ppm. $\left.{ }^{13} \mathrm{C} \mathrm{NMR}\left(\mathrm{CDCl}_{3}\right): \delta=28.04\left(\mathrm{C}_{(\mathrm{CH}}\right)_{3}\right), 52.49\left(\mathrm{OCH}_{3}\right), 81.18\left(\mathrm{OC}\left(\mathrm{CH}_{3}\right)_{3}\right), 82.50(\mathrm{C}), 104.35(\mathrm{C})$, $107.49(\mathrm{CH}), 111.32(\mathrm{C}), 114.53(\mathrm{CH}), 133.27(\mathrm{CH}), 133.35(\mathrm{C}), 147.58(\mathrm{C}), 151.97(\mathrm{C}=\mathrm{O}), 164.56(\mathrm{C}=\mathrm{O}) \mathrm{ppm}$. $\mathrm{C}_{17} \mathrm{H}_{20} \mathrm{~N}_{2} \mathrm{O}_{4}$ (316.36): calcd. C 64.54, H 6.37, N 8.86; found C 64.27, H 6.09, N 8.84.

Boc-(E)- $\Delta$ Ala $\{\beta$-[2-(4-bromophenyl)ethynyl]\}-OMe (E)-1c:Column chromatography using as solvent gradient from neat petroleum ether to $40 \%$ ether/petroleum ether, gave product $(\boldsymbol{E})-\mathbf{1 c}(304 \mathrm{mg}, 80 \%)$ as a solid. Recrystallization from ether/petroleum ether gave colourless crystals, mp 123.1-124.1 ${ }^{\circ} \mathrm{C} .{ }^{1} \mathrm{H}$ NMR $\left(\mathrm{CDCl}_{3}\right): \delta=$ 1.49 (s, 9H, $\mathrm{CH}_{3} \mathrm{Boc}$ ), 3.84 (s, 3H, $\mathrm{OCH}_{3}$ ), 6.27 (s, $\left.1 \mathrm{H}, \beta \mathrm{CH}\right), 6.59$ (broad s, $\left.1 \mathrm{H}, \mathrm{NH}\right), 7.32$ (d, J=8.4 Hz, 2H, ArH

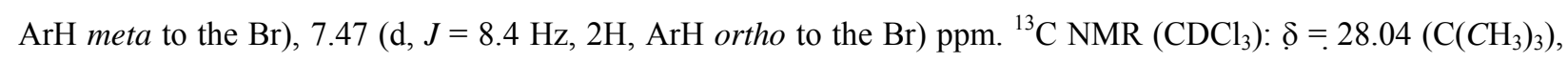
$52.75\left(\mathrm{OCH}_{3}\right), 81.46\left(\mathrm{OC}\left(\mathrm{CH}_{3}\right)_{3}\right), 85.22(\mathrm{C}), 101.34(\mathrm{C}), 105.41(\mathrm{CH}), 121.45(\mathrm{C}), 123.37(\mathrm{C}), 131.65(\mathrm{CH}), 133.03$ $(\mathrm{CH}), 134.88(\mathrm{C}), 151.48(\mathrm{C}=\mathrm{O}), 164.29(\mathrm{C}=\mathrm{O}) \mathrm{ppm} . \mathrm{C}_{17} \mathrm{H}_{18} \mathrm{NO}_{4} \mathrm{Br}$ (380.24): calcd. C 53.70, H 4.77, N 3.68; found C 53.85, H 4.89, N 3.72 .

General procedure for Sonogashira Cross Coupling using the methyl ester of $N$-(tert-butoxycarbonyl)- $\beta, \beta$ dibromodehydroalanine and phenylacetylenes: To a solution of compound $\mathrm{Boc}-\Delta \mathrm{Ala}(\beta, \beta-\mathrm{Br})-\mathrm{OMe}(0.5 \mathrm{mmol}$; $180 \mathrm{mg}$ ) in acetonitrile $(5 \mathrm{~mL})$, $\mathrm{CuI}(20 \mathrm{~mol} \%, 20.0 \mathrm{mg}), \mathrm{PdCl}_{2}\left(\mathrm{PPh}_{3}\right)_{2}(10 \mathrm{~mol} \%$; $36.0 \mathrm{mg}), \mathrm{Cs}_{2} \mathrm{CO}_{3}$ (1.4 equiv., $228 \mathrm{mg}$ ) were added, followed by the alkyne (4 equiv.), with rapid stirring at $85^{\circ} \mathrm{C}$ for $1 \mathrm{~h} 30 \mathrm{~min}$, under argon. The acetonitrile was removed under reduced pressure and the residue was dissolved in $15 \mathrm{~mL}$ of ethyl acetate. The organic layer was then washed with water and brine $\left(2 \times 15 \mathrm{~mL}\right.$ each), dried over $\mathrm{MgSO}_{4}$ and evaporated at reduced pressure giving an oil, which was submitted to column chromatography on silica.

Boc- $\Delta$ Ala $\{\beta, \beta$-bis-[2-(phenyl)ethynyl]\}-OMe (2a): Column chromatography using solvent gradient from neat petroleum ether to $80 \%$ ether/petroleum ether, gave as less polar product the dimer of the phenylacetylene (22.0mg) as a white solid $85-87^{\circ} \mathrm{C},{ }^{1} \mathrm{H}$ NMR $\left(\mathrm{CDCl}_{3}\right): \delta=7.35-7.38(\mathrm{~m}, 6 \mathrm{H}, \mathrm{ArH}), 7.53-7.56(\mathrm{~m}, 4 \mathrm{H}, \mathrm{ArH}) \mathrm{ppm}$, followed by compound 2a (104 mg, 52\%) as an oil. Recrystallization from ether/petroleum ether gave colourless crystals, mp 113.7-114.0 ${ }^{\circ} \mathrm{C} .{ }^{1} \mathrm{H}$ NMR $\left(\mathrm{CDCl}_{3}\right): \delta=1.50$ (s, 9H, $\mathrm{CH}_{3} \mathrm{Boc}$ ), 3.95 (s, 3H, $\left.\mathrm{OCH}_{3}\right), 6.96$ (broad s, $\left.1 \mathrm{H}, \mathrm{NH}\right), 7.32-$ 7.34 (m, 3H, ArH), 7.38-7.40 (m, 3H, ArH), 7.46-7.49 (m, 2H, ArH), 7.53-7.56 (m, 2H, ArH) ppm. ${ }^{13} \mathrm{C}$ NMR

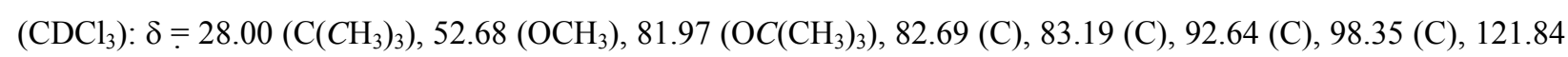


(C), $122.61(\mathrm{C}), 128.26(\mathrm{CH}), 128.45(\mathrm{CH}), 128.56(\mathrm{CH}), 129.23(\mathrm{CH}), 131.53(\mathrm{CH}), 131.72(\mathrm{CH}), 140.53(\mathrm{C})$, $150.74(\mathrm{C}=\mathrm{O}), 163.33(\mathrm{C}=\mathrm{O})$ ppm. $\mathrm{C}_{25} \mathrm{H}_{23} \mathrm{NO}_{4}$ (401.46): calcd. C 74.80, H 5.77, N 3.49; found C 74.69, H 5.87, N 3.53. Compound (E)-1a (22.0 $\mathrm{mg}, 14 \%)$ was isolated as a more polar product.

Boc- $\Delta$ Ala $\{\beta, \beta$-bis-[2-(4-aminophenyl)ethynyl]\}-OMe (2b): Column chromatography using solvent gradient from neat petroleum ether to $80 \%$ ether/petroleum ether, gave as less polar product compound $(\boldsymbol{E})-\mathbf{1 b}(16 \mathrm{mg}, 10 \%)$ followed by the dimer of 4-aminophenylacetylene as a solid $(50.0 \mathrm{mg})$ m.p. $220-222{ }^{\circ} \mathrm{C},{ }^{1} \mathrm{H} \mathrm{NMR}\left(\mathrm{CDCl}_{3}\right): \delta=3.88$ (broad s, $4 \mathrm{H}, 2 \mathrm{xNH}_{2}$ ), 6.60 (d, $4 \mathrm{H}, J=9 \mathrm{~Hz}, 2 \mathrm{xArH}$ ortho to $\mathrm{NH}_{2}$ ) 7.32 (d, $4 \mathrm{H}, J=9 \mathrm{~Hz}, 2 \mathrm{xArH} m$ to $\mathrm{NH}_{2}$ ) ppm, $\mathrm{C}_{16} \mathrm{H}_{12} \mathrm{~N}_{2}$ (232.28): calcd. C 82.73, H 5.21, N 12.06; found C 82.47, H 5.49, N 12.05. As more polar product, compound $2 \mathbf{b}$ was isolated as an oil $(93.0 \mathrm{mg}, 44 \%)$. Recrystallization from diethyl ether/n-hexane gave yellow solid, mp 129.6-131.8 ${ }^{\circ} \mathrm{C} .{ }^{1} \mathrm{H}$ NMR $\left(\mathrm{CDCl}_{3}\right): \delta=1.43$ (s, 9H, $\mathrm{CH}_{3} \mathrm{Boc}$ ), $3.84\left(\right.$ broad s, $\left.4 \mathrm{H}, \mathrm{NH}_{2}\right), 3.93(\mathrm{~s}, 3 \mathrm{H}$, $\left.\mathrm{OCH}_{3}\right), 6.26(\mathrm{~s}, 1 \mathrm{H}, \mathrm{NH}), 6.63\left(\mathrm{~d}, J=8.7 \mathrm{~Hz}, 2 \mathrm{H}, \mathrm{ArH}\right.$ ortho to the $\left.\mathrm{NH}_{2}\right), 6.68(\mathrm{~d}, J=8.7 \mathrm{~Hz}, 2 \mathrm{H}, \mathrm{ArH}$ ortho to the $\left.\mathrm{NH}_{2}\right), 7.23\left(\mathrm{~d}, J=8.7 \mathrm{~Hz}, 2 \mathrm{H}\right.$, ArH meta to the $\left.\mathrm{NH}_{2}\right), 7.34\left(\mathrm{~d}, J=8.7 \mathrm{~Hz}, 2 \mathrm{H}\right.$, ArH meta to the $\left.\mathrm{NH}_{2}\right) \mathrm{ppm}$. ${ }^{13} \mathrm{C} \mathrm{NMR}$

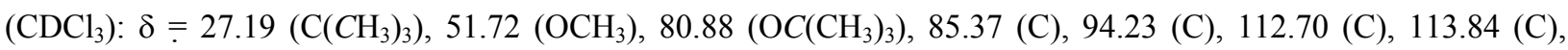
$114.35(\mathrm{CH}), 114.65(\mathrm{CH}), 120.81(\mathrm{C}), 124.34(\mathrm{C}), 130.15(\mathrm{CH}), 132.93(\mathrm{CH}), 139.05(\mathrm{C}), 146.66(\mathrm{C}), 146.91(\mathrm{C})$, 149.26 (C), $160.51(\mathrm{C}=\mathrm{O}), 170.71(\mathrm{C}=\mathrm{O}) \mathrm{ppm}$. MS: $\mathrm{m} / \mathrm{z}(\%)=431(20)\left[\mathrm{M}^{+}\right], 331(100)\left[\mathrm{M}^{+}\right.$- Boc], 299 (49), 270 (42). HRMS: calcd. for $\mathrm{C}_{25} \mathrm{H}_{25} \mathrm{~N}_{3} \mathrm{O}_{4}\left[\mathrm{M}^{+}\right]$431.1844; found 431.1845 .

Boc- $\Delta$ Ala $\{\beta, \beta$-bis-[2-(4-bromophenyl)ethynyl]\}-OMe (2c): Column chromatography using solvent gradient from neat petroleum ether to $20 \%$ ether/petroleum ether, gave as less polar product the dimer of 4-bromophenylacetylene as a solid (10mg), m.p. $257-258{ }^{\circ} \mathrm{C},{ }^{1} \mathrm{H}$ NMR $\left(\mathrm{CDCl}_{3}\right): \delta=7.39(\mathrm{~d}, 4 \mathrm{H}, J=8.7 \mathrm{~Hz}, 2 \mathrm{xArH}$ meta to $\mathrm{Br}) 7.49(\mathrm{~d}, 4 \mathrm{H}$, $J=8.7 \mathrm{~Hz}, 2 \mathrm{xArH}$ ortho to $\mathrm{Br}$ ) ppm, $\mathrm{C}_{16} \mathrm{H}_{8} \mathrm{Br}_{2}$ (360.05): calcd. C 53.37, H 2.24; found C 53.28, H 2.27, followed by compound 3c which was isolated as a white solid (177 mg, 63\%). Recrystallization from ether/petroleum ether gave a white crystals, mp 175.6-176.1 ${ }^{\circ} \mathrm{C} .{ }^{1} \mathrm{H}$ NMR $\left(\mathrm{CDCl}_{3}\right): \delta=1.50\left(\mathrm{~s}, 9 \mathrm{H}, \mathrm{CH}_{3} \mathrm{Boc}\right), 3.93\left(\mathrm{~s}, 3 \mathrm{H}, \mathrm{OCH}_{3}\right), 6.93$ (broad s, 1H, NH), 7.32 (d, $J=8.4 \mathrm{~Hz}, 2 \mathrm{H}, \mathrm{ArH}$ meta to the $\mathrm{Br}$ ), 7.39 (d, $J=8.4 \mathrm{~Hz}, 2 \mathrm{H}$, ArH meta to the $\mathrm{Br}$ ), 7.46 (d, $J=8.4 \mathrm{~Hz}, 2 \mathrm{H}$, ArH ortho to the $\mathrm{Br}$ ), $7.52\left(\mathrm{~d}, J=8.4 \mathrm{~Hz}, 2 \mathrm{H}\right.$, ArH ortho to the $\mathrm{Br}$ ) ppm. ${ }^{13} \mathrm{C} \mathrm{NMR}\left(\mathrm{CDCl}_{3}\right): \delta=$ $28.01\left(\mathrm{C}\left(\mathrm{CH}_{3}\right)_{3}\right), 52.79\left(\mathrm{OCH}_{3}\right), 82.83(\mathrm{C}), 82.98(\mathrm{C}), 84.12(\mathrm{C}), 91.66(\mathrm{C}), 97.35(\mathrm{C}), 120.78(\mathrm{C}), 121.50(\mathrm{C})$, $122.95(\mathrm{C}), 123.74(\mathrm{C}), 131.60(\mathrm{CH}), 131.80(\mathrm{CH}), 132.94(\mathrm{CH}), 133.11(\mathrm{CH}), 141.09(\mathrm{C}), 150.60(\mathrm{C}), 163.17$ $(\mathrm{C}=\mathrm{O}), 170.76(\mathrm{C}=\mathrm{O}) \mathrm{ppm} . \mathrm{C}_{25} \mathrm{H}_{21} \mathrm{NO}_{4} \mathrm{Br}_{2}$ (559.25): calcd. C 53.69, H 3.78, N 2.50; found $\mathrm{C} 53.68, \mathrm{H}$ 4.01, N 2.60. As more polar product compound $(\boldsymbol{E})-\mathbf{1 c}(31 \mathrm{mg}, 16 \%)$ was isolated.

\section{Suzuki Coupling:}

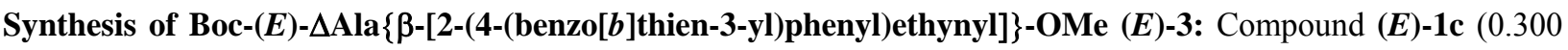
$\mathrm{mmol}, 114 \mathrm{mg})$ was coupled with 3-boronic benzo[b]thienyl acid $(0.330 \mathrm{mmol}, 59.0 \mathrm{mg})$ using $\mathrm{Pd}\left(\mathrm{PPh}_{3}\right)_{4}$ $(0.03 \mathrm{mmol}, 35.0 \mathrm{mg})$ and $\mathrm{Na}_{2} \mathrm{CO}_{3}(0.600 \mathrm{mmol}, 63.6 \mathrm{mg})$ in DME/ $\mathrm{H}_{2} \mathrm{O}(10: 1)$ at $90{ }^{\circ} \mathrm{C}$, for 3 hours. After cooling, water and ethyl acetate were added and the phases were separated. The organic phase was washed with brine, dried over $\mathrm{MgSO}_{4}$, filtered, and evaporated at reduce pressure to give an oil. Column chromatography on silica using as solvent gradient from neat petroleum to $30 \%$ diethyl ether/petroleum, gave product $(\boldsymbol{E})-3(65.0 \mathrm{mg}, 50 \%)$ as a white solid. Recrystallization from diethyl ether/petroleum ether gave colourless crystals, mp 142.8-144.0 ${ }^{\circ} \mathrm{C}$. ${ }^{1} \mathrm{H}$ NMR $\left(\mathrm{CDCl}_{3}\right): \delta=1.53\left(\mathrm{~s}, 9 \mathrm{H}, \mathrm{CH}_{3} \mathrm{Boc}\right), 3.87\left(\mathrm{~s}, 3 \mathrm{H}, \mathrm{OCH}_{3}\right), 6.32(\mathrm{~s}, 1 \mathrm{H}, \beta \mathrm{CH}), 6.58(\mathrm{~s}, 1 \mathrm{H}, \mathrm{NH}), 7.40-7.44(\mathrm{~m}, 2 \mathrm{H}$, 


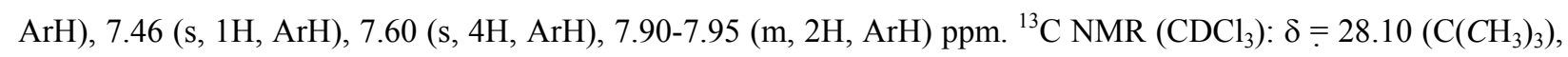
$52.72\left(\mathrm{OCH}_{3}\right), 81.47\left(\mathrm{OC}\left(\mathrm{CH}_{3}\right)_{3}\right), 84.78(\mathrm{C}), 102.45(\mathrm{C}), 105.77(\mathrm{CH}), 121.58(\mathrm{C}), 122.66(\mathrm{CH}), 122.98(\mathrm{CH})$, $124.12(\mathrm{CH}), 124.50(\mathrm{CH}), 124.56(\mathrm{CH}), 128.59(\mathrm{CH}), 132.10(\mathrm{CH}), 134.85(\mathrm{C}), 136.70(\mathrm{C}), 137.12(\mathrm{C}), 137.40$

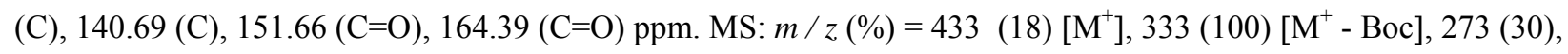
245 (23). HRMS: calcd. for $\mathrm{C}_{25} \mathrm{H}_{23} \mathrm{NO}_{4} \mathrm{~S}\left[\mathrm{M}^{+}\right]$433.1328; found 433.1348.

\section{C-N cross-coupling:}

Synthesis of Boc- $\Delta$ Ala $\{\beta, \beta$-bis-[2-(4-amino(2,3-dimethylbenzo[b]thien-7-yl)phenyl)ethynyl]\}-OMe (4): A dried Schlenk tube was charged under Ar with dry toluene $(1.5 \mathrm{~mL})$ and compound $2 \mathrm{c}(0.150 \mathrm{mmol}, 84.0 \mathrm{mg})$ and the mixture was heated for $10 \mathrm{~min}$ at $80{ }^{\circ} \mathrm{C} . \mathrm{Pd}(\mathrm{OAc})_{2}(0.0300 \mathrm{mmol}, 6.73 \mathrm{mg})$, BINAP $(0.0450 \mathrm{mmol}, 28.0 \mathrm{mg})$ and $\mathrm{Cs}_{2} \mathrm{CO}_{3}(0.420 \mathrm{mmol}, 137 \mathrm{mg})$ were added and the mixture was heated for another $10 \mathrm{~min}$. at $80^{\circ} \mathrm{C}$. The 7 -amino2,3-dimethylbenzo[b]thiophene $(0.300 \mathrm{mmol}, 53 \mathrm{mg})$ was added in dry toluene $(1.5 \mathrm{~mL})$ and the mixture was heated with stirring at $100{ }^{\circ} \mathrm{C}$ under Ar for ca. $1 \mathrm{~h} 30 \mathrm{~min}$.. After cooling, water and diethyl ether were added, the phases were separated, and then the aqueous phase was washed with diethyl ether $(3 \times 10 \mathrm{~mL})$. The organic phase was collected, dried over $\mathrm{MgSO}_{4}$, filtered, and then the solvent was evaporated at reduce pressure giving a brown oil, which was subjected to column chromatography after traces of toluene were evaporated using $\mathrm{MeOH}$. Solvent gradient was used from neat petroleum to $50 \%$ diethyl ether/petroleum ether, giving product $4(44 \mathrm{mg}, 40 \%)$ as a brown oil. ${ }^{1} \mathrm{H}$ NMR $\left(\mathrm{CDCl}_{3}\right)$ : $\delta=1.47$ (s, 9H, $\mathrm{CH}_{3} \mathrm{Boc}$ ), 2.33 (s, $6 \mathrm{H}, 2 \mathrm{x} \mathrm{CH}_{3}$ ), 2.50 (s, $6 \mathrm{H}, 2 \mathrm{x} \mathrm{CH}_{3}$ ), 3.95 (s, 3H, $\mathrm{OCH}_{3}$ ), 5.73 (broad s, 2H, 2 x NH), $6.33(\mathrm{~s}, 1 \mathrm{H}, \mathrm{NH}), 6.97$ (d, 2H, $\left.J=9.0 \mathrm{~Hz}, \mathrm{ArH}\right), 7.02(\mathrm{~d}, 2 \mathrm{H}, J=8.7 \mathrm{~Hz}, \mathrm{ArH})$, $7.23(\mathrm{dd}, 2 \mathrm{H}, J=6.3$ and $2.4 \mathrm{~Hz}, \mathrm{ArH}), 7.34(\mathrm{~d}, 6 \mathrm{H}, J=6.6 \mathrm{~Hz}, \mathrm{ArH}), 7.43(\mathrm{~d}, 2 \mathrm{H}, J=8.7 \mathrm{~Hz}, \mathrm{ArH}) \mathrm{ppm} .{ }^{13} \mathrm{C} \mathrm{NMR}$

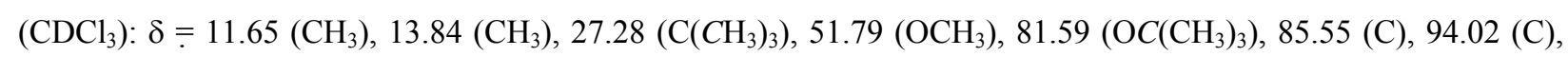
$113.53(\mathrm{CH}), 113.67(\mathrm{C}), 114.13(\mathrm{CH}), 114.48(\mathrm{CH}), 114.78(\mathrm{C}), 116.25(\mathrm{CH}), 116.29(\mathrm{CH}), 116.40(\mathrm{CH}), 116.45$ $(\mathrm{CH}), 122.81(\mathrm{C}), 124.76(\mathrm{C}), 124.95(\mathrm{CH}), 128.12(\mathrm{C}), 128.15(\mathrm{C}), 130.04(\mathrm{CH}), 130.53(\mathrm{C}), 130.74(\mathrm{C}), 132.82$ (CH), 133.26 (C), 133.34 (C), 135.83 (C), 136.08 (C), 138.71 (C), 142.78 (C), 143.54 (C), 143.81 (C), 149.20 $(\mathrm{C}=\mathrm{O}), 160.50(\mathrm{C}=\mathrm{O}) \mathrm{ppm}$. MS (FAB): $\mathrm{m} / \mathrm{z}(\%)=752(26)\left[\mathrm{M}^{+}+\mathrm{H}\right], 751(26)\left[\mathrm{M}^{+}\right] 652(36)\left[\mathrm{M}^{+}+\mathrm{H}-\mathrm{Boc}\right] 651(53)$ $\left[\mathrm{M}^{+}\right.$- Boc]. HRMS: $\mathrm{C}_{45} \mathrm{H}_{42} \mathrm{~N}_{3} \mathrm{O}_{4} \mathrm{~S}_{2}\left[\mathrm{M}^{+}+\mathrm{H}\right]^{+} 752.2617$; found 752.2635 .

\section{Acknowledgments}

Foundation for the Science and Technology (Portugal) for financial support to: IBQF-Univ. Minho, POCTI/99/QUI/32689 project and to SFRH/BD/4709/2001 PhD financial support of A.S. Abreu.

\section{References:}

${ }^{[1]}$ P. M. T. Ferreira, H. Maia, L. S. Monteiro, Eur. J. Org. Chem., 2003, 2635-2644, and references cited therein.

${ }^{[2]}{ }^{[2 a]}$ B. Stanovick, J. Svete, Synlett 2000, 1077-1091 and references cited therein. ${ }^{[2 b]}$ J. Svete, J. Het. Chem., 2002, 39, 437-454 and references cited therein.

${ }^{[3]}$ A. S. Abreu, N.O. Silva, P. M. T. Ferreira, M.-J. R. P. Queiroz, M. Venanzi, Eur. J. Org. Chem., 2003, 47924796. 
${ }^{[4]}{ }^{[4 a]}$ N.O. Silva, A. S. Abreu, P. M. T. Ferreira, L.S. Monteiro and M.-J. R. P. Queiroz, Eur. J. Org. Chem., 2002, 2524-2528. ${ }^{[4 b]}$ A. S. Abreu, N. O. Silva, P.M.T. Ferreira, M.-J. R. P. Queiroz, Eur. J. Org. Chem., 2003, 1537-1544.

${ }^{[4 c]}$ A. S. Abreu, N. O. Silva, P.M.T. Ferreira, M.-J. R. P. Queiroz, Tetrahedron Lett., 2003, 44, 3377-3379.

${ }^{[5]}$ F. P. J. T. Rutjes, L. B. Wolf, H. E. Schoemaker, J. Chem. Trans., Perkin Trans. 1, 2000, 4197-4212.

${ }^{[6]}$ G. T. Crisp, Y.-L. Jiang, P. J. Pullman, C. De Savi, Tetrahedron, 1997, 53, 17489-17500.

[7] B.C. J. van Esseveldt, F. L. van Delft, , R. de Gelder, F.P.J.T. Rutjes, Org. Lett., 2003, 5, 1717-1720.

${ }^{[8]}$ M. P. López-Deber, L. Castedo, J. R. Granja, Org. Lett., 2001, 3, 2823-2826.

${ }^{[9]}$ K. Sonogashira, J. Organomet. Chem., 2002, 653 (1-2), 46-49.

${ }^{[10]}$ J. Uenishi, K. Matsui, H. Ohmiya, J. Organomet. Chem., 2002, 653, 141-149.

${ }^{[11]}$ Z. R. Grabowski, K. Rotkiewicz, W. Rettig, Chem.Rev., 2003, 103, 3899-4031. 